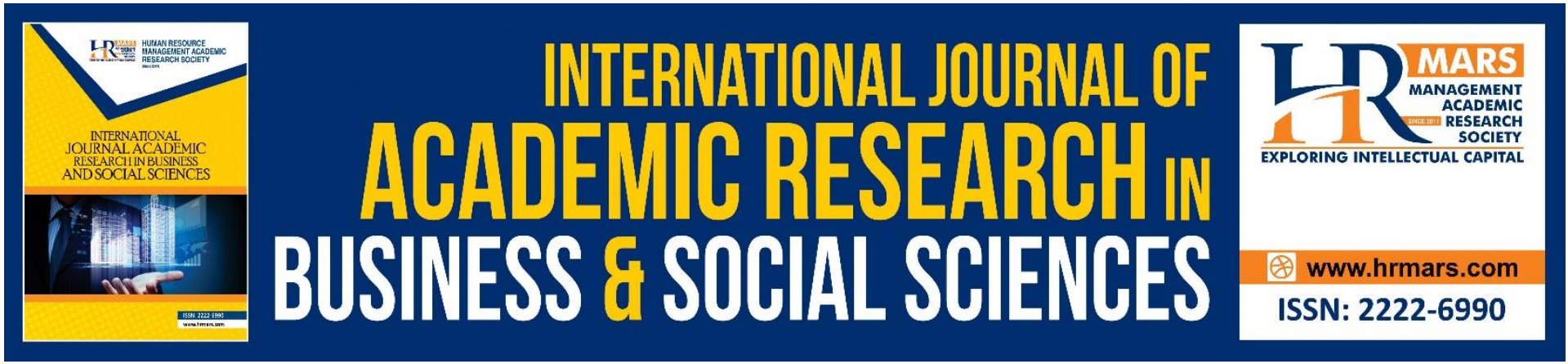

\title{
Strategic Leadership Practices and Reforms Implementation in Selected National Police Divisions, Nairobi City County, Kenya.
}

Awino Topister, Philip Wambua

To Link this Article: http://dx.doi.org/10.6007/IJARBSS/v10-i12/8386

DOI:10.6007/IJARBSS/v10-i12/8386

Received: 11 October 2020, Revised: 13 November 2020, Accepted: 28 November 2020

Published Online: 17 December 2020

In-Text Citation: (Topister \& Wambua, 2020)

To Cite this Article: Topister, A., \& Wambua, P. (2020). Strategic Leadership Practices and Reforms Implementation in Selected National Police Divisions, Nairobi City County, Kenya. International Journal of Academic Research in Business and Social Sciences, 10(12), 939-949.

Copyright: (C) 2020 The Author(s)

Published by Human Resource Management Academic Research Society (www.hrmars.com)

This article is published under the Creative Commons Attribution (CC BY 4.0) license. Anyone may reproduce, distribute, translate and create derivative works of this article (for both commercial and non-commercial purposes), subject to full attribution to the original publication and authors. The full terms of this license may be seen at: http://creativecommons.org/licences/by/4.0/legalcode

Vol. 10, No. 12, 2020, Pg. 939 - 949

Full Terms \& Conditions of access and use can be found at http://hrmars.com/index.php/pages/detail/publication-ethics 


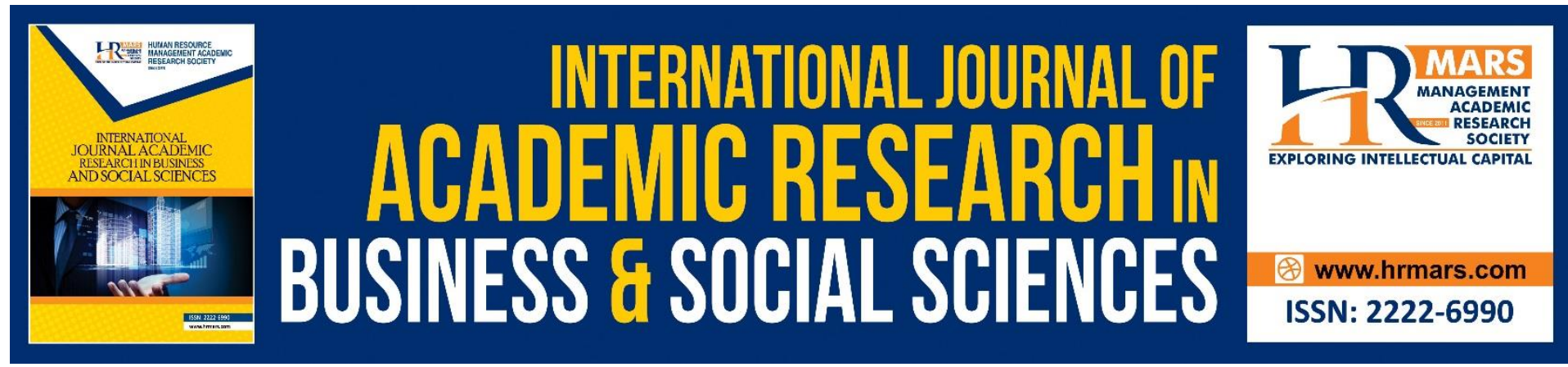

\title{
Strategic Leadership Practices and Reforms Implementation in Selected National Police Divisions, Nairobi City County, Kenya.
}

\author{
Awino Topister, Dr. Philip Wambua \\ Lecturer Kenyatta University, MBA student at Kenyatta University \\ Department of Business Administration, Strategic Management Option, Kenyatta University, \\ Kenya. \\ Email: topyawino@gmail.com
}

\begin{abstract}
This article discusses the strategic leadership practices employed by police leaders in Kenya to ensure that reforms are implemented in the Police Service. The article aimed particularly at four major dimensions: employee empowerment, teamwork, resource mobilization and visionary leadership to ensure successful implementation of police reforms. The data emphasizing on leadership practices were gathered from eight police divisions within Nairobi county. Data analysis was presented in tables to derive and contemplate on leadership practices of police leaders in Kenya. The findings indicate that police leaders played a very big role in reforms implementation.
\end{abstract}

Keywords: Strategic Leadership Practices, Reforms Implementation.

\section{Introduction}

Reforms are act of transforming or amending firm for it to be improved. According to Caiden (2008), reform implementation is the carrying out of analytical transformation in the departmental or administrative structure which is formed to drive to a more productive, effective and systematic administration. It deals with re-positioning or reporting of an organization for effectiveness and efficiency. Reforms are responsibilities of the management of organizations, which is sanctioned to selective aspects of a given firm sectional, total overhaul or complete reversal of the institution. The clear statement of what is supposed to be changed or transformed and the earned results of reform is always the responsibility of the top and middle administration in the organization.

According to the study done by Escobar (2001), the implementation of the Kenyan constitution took place in 2010 by the Kenya Law Reform Commission. This form part of the major reforms that have been implemented in Kenya as a country. The Kenya Law Reform Commission was established as one of the bodies that were to make legislation and to implement the constitution. This body worked together with the Attorney general and MoJNCCA to draft the commission of implementation of the constitutional bill. Kenya Law Reform Commission played a very important role in ensuring that the Kenya constitution was fully and timely implemented. It came up with a strategic plan which gave new insight by 
carrying out its work and also used to ensure success of putting the Kenyan constitution into effect. Kenya Law Reform Commission adopted participatory also consultative process bearing in mind that this was a new process within the institution.

The National Police Service is currently undergoing some comprehensive policing reforms (Kenya Police 2009). It was established that in the whole Africa, Kenya is the only African country that is undertaking the largest and comprehensive policing reform program. According to Constitution of Kenya (2010), there are some police reforms which have already been implemented. They include: establishment of National Police Service (NPS), new leadership structure introduction, vetting of police leaders, merging of the two police services, decent housing, formation of National Police Service Commission as well as the creation of the Internal Affair Unit alongside the Advent of Independent Policing Oversight Authority (IPOA). According to study done by Human Rights (2016), the journey to police reforms started in 2003, since then, a bigger percentage of the proposed reforms have already been put in place and a lot still need to be done. In 2009, the government established a Police Reforms Implementation Committee (PRIC) responsible for organizing and facilitating the process of National Police service reforms. Top police leaders were also included in the committee to highly participate in facilitating and implementing police reforms.

Many countries across the globe including United Kingdom (UK) have recently experienced various reforms in their policing operations, techniques and philosophy accompanied by commensurate rise in demand of relevant strategic leadership practices, According to $\mathrm{KNCHR}(2015)$, strategic leadership practices in Kenya have assisted in the processes of introducing reforms in the service while at the same time investing in measures to escalate the success rates of the adoption of such paradigm shifts in National Police Service. There are several legislations that were formed in Kenya to support reforms implementation in the National Police Service, for example Independence Policing Oversight Authority, National police service commission and National police service Act. Amnesty International (2013), despite the formation of all these legislation, police reforms implementation was not successful until when the police leadership started playing part in the implementation of the same. "tracked changes" This concern lead the researcher to identify some of four objectives, which were the point of focus during the study. They include: to establish the extent to which employee empowerment influences reforms implementation in the selected National Police divisions in the County of Nairobi, to find out how teamwork affect reforms implementation in the selected National Police divisions, Nairobi County, Kenya, to investigate how resource mobilization influence reforms implementation in the selected National Police divisions in the County of Nairobi and to analyze the effects of visionary leadership on the reforms implementation in the selected National Police divisions in the County of Nairobi, the study looked into these issues which helped in answering the general question as to whether the police leadership practices affect the reforms implementation in the National Police Service. Previous local studies have been conducted in relation to police reforms. Mutua (2014), did a study on police reforms and service delivery where he concluded that enumeration, improved training and police reforms would improve service delivery. Mutua's study relates to this study whereby it emphasized on training as one of the measures of the dependent variables in this study. Kabia (2013), also did a research pertaining factors that influence the perception of police officers on changes within the police force in service delivery in Kenya Police where he found out that there existed relationship between perception of police officers on police reforms and training, recruitment, and legal structural terms of the service. Chtalu (2014), investigated challenges that relate to the effectuation of police reforms. This study has a close 
link with this research where it focuses on the same aspect of reforms. However, their studies were not specific on the leadership shifts, this is a gap that emerged from previous scholarly works. Moreover, there are conceptual and contextual gaps evident from the previous studies since none of the studies focused on strategic leadership practices and reforms implementation in Kenya focusing on the National Police Service. In addition, most of these studies were largely based on descriptive analysis hence an in depth analysis of strategic leadership and reforms implementation in police service was conducted in the current investigation.

\section{Review of the Literature}

A number of empirical studies have found out that reforms in an organization goes hand in hand with leadership styles. In his research, ChitaluBruice (2014) investigated on the issues arising from police reforms in Kenya. He analyzed it using Kurt Lewin's change theory. The research established that the knowledge of police reforms among the police officers was very low and implementation of new ranks and police vetting was very difficult. John Kabia (2013), also examined the factors affecting police perception on police reforms. The study found out that the existence of relationship between perception of police officers on police reforms and training, recruitment, staffing, and legal structures of the service.

Charles Mutua (2014) carried out a study on the effectiveness of Kenya Police reforms on Service delivery. The research concluded that not all reforms are successful and due to this, commission in charge of police reforms must highly be cautious in identifying types of reforms to put in place in order to come up with effective service delivery.

KevinahWepukhulu (2012) in his research on Impact of teamwork on performance in the energy sector. His findings showed that both the external and internal factors that influence team building for example culture, employee, top management perception, resources and organizational policy should be addressed for an organization to be productive.

In their research, Odenyo Collins and Rosemary James investigated on the Impact of mobilization of Resources in the sustenance of women groups in the Western Kenya county of Vihiga. Their investigation came to a conclusion that sustaining the projects by women groups is largely a factor of sufficiency of resources.

\section{Materials and methods Research Design}

These are sets of methods, procedures and techniques that are selected and combined in the study in reasonable and logical manner so as to efficiently handle research problem. This project adopted descriptive design since it is a method used to collect data by use of questionnaires from sample chosen in a target population. Orodho (2003), discovered that descriptive survey is chosen since it gives out an in depth information from respondents and also it enabled the researcher to discover new ideas because it gives opportunity of considering different aspects under study.

\section{Target Population}

Mugenda and Mugenda (2003) classified that target population as the people or elements having similar or common characteristics established by a researcher from which a sample shall be drawn. According to Police Personal Data (2019), the eight selected police divisions within Nairobi County has a total of 445 police leaders cutting across the ranks of senior 
superintendent of police to non-commissioned officers (NCO's). The researcher obtained a population target of 445 police leaders.

\section{Sampling Design}

Ngechu (2004), defined sampling as a mathematical function used for selecting people or observation from the entire target randomly and without being biased for the purpose of making fair generalization of the results obtained from the sample. The National Police Service has a population of about 92, 000 police officers deployed in different departments across the country. Therefore, the researcher did not manage to study the entire population of National Police Service, thus she attempted to define an experimentally accessible population. The sample was randomly picked from the eight out of fourteen police divisions in Nairobi County and about twenty-two police stations were visited.

The researcher combined purposive, stratified and simple random sampling procedure, population was grouped in three strata then sample was collected from every stratum. In order to capture the validity of characteristics amongst those within the study population, the sample population was grouped into three sub groups based on homogeneity, and incorporated the NCO's, members of inspectorate alongside gazette officers. In this research, classification basis was ranks.

\section{Data Collection Instruments}

Mugenda and Mugenda (2008), defined data as anything that is given out as facts on which research inference was based. In the current study, the researcher collected data from primary source. For collecting primary data in this study the questionnaire simply used. However, questionnaire used carried close-ended questions to qualitative and quantitative data. Sapsford (2009), states that questionnaires are mostly used because they are not costlier and also they are not biased in nature, it also gives the respondent enough time to give well thought answers hence making the answers more reliable in giving the best over view of research study. The Drop and pick method was applied in order to give out the questionnaire to the chosen sample. Reliability of questionnaire was ensured by carefully restructuring questions and confirming the layout to ensure it is simple to understand.

\section{Pilot Study}

William (2005) defined pilot study as a preliminary study conducted to evaluate the logistics before conducting the real or actual study. A pilot study was conducted at Nairobi Railways Police Station since the station was not part of the target selection, whereby fifteen police leaders participated. The researcher did this so that she could fulfill the gaps, shortages and deficiencies that may have been found in design instruments. It also helped in confirming whether the items and instructions in the questionnaire were clear and understandable.

\section{Validity and Reliability of Research Instruments Validity of Research Instruments}

Kothari (2004) defines that validity is extent of which scores from a measure measures the right elements that are intended to be measured. The content of validity was measured using the expert's opinion in the field of study. To validate the instruments, a supervisor was consulted whereby his opinions and criticisms were used to improve the research validity. According to Javid (2015), the types of validity that are measured in research study are: 
criterion, content and construct validity. Content validity was used to test representativeness and suitability of the questions in the questionnaire.

\section{Reliability of Research Instruments}

Orodho (2012) describes the subject of reliability as degree that experiments or any other measuring procedures remain consistent, or at worse, have a slight deviation. The reliability of questionnaire was measured using the consistency of responses to the researcher's questions (Michelle, 1996). This study's reliability was measured by Cronbach's Alpha where 0.6 was the cut level and above was accepted.

\section{Data Collection Procedures}

An introductory letter was obtained from Kenyatta University. Thereafter, data collection permission letter was obtained from NACOSTI. Consequently, the researcher booked an appointment with the Sample police divisions through sub county police commanders (OCPD's) to visit the division headquarters and administer the questionnaires to respondents. Thereafter, the researcher collected them after the agreed time with the respondents. This method is called pick latter method. The study collected primary data. Semi-structured questionnaires facilitated in collection of primary data, this is according to (Mugenda and Mugenda, 2003) where he also states that questionnaires are suitable in obtaining the population's important information.

\section{Data Analysis and Presentation}

Raw data was edited first so as to detect whether there are some errors or omissions and thereafter corrections were done. The researcher coded the data for efficiency and classified it on basis of attributes and characteristics. Analyzing of data was done using (SPSS) program and presented by pie charts and distribution table. Qualitative data were coded mathematically guided by research objectives. According to Bhaskar (2016) described regression analysis as statistical tool for analyzing the relationships of dependent and independent variable. Therefore, the study adopted regression to do quantitative data analysis.

$$
Y=b_{0}+b_{1} X_{1}+b_{2} X_{2}+b_{3} X_{3}+b_{4} X_{4}+e
$$

Where $\mathbf{Y}=$ Reforms implementation

$\mathbf{b}_{\mathbf{0}}=$ The intercept $/$ Constant

$\mathbf{b}_{1}, \mathbf{b}_{2}, \mathbf{b}_{3}$ and $\mathbf{b}_{\mathbf{4}}=$ The coefficients

$\mathbf{X}_{\mathbf{1}}=$ Employee Empowerment

$\mathbf{X}_{2}=$ Teamwork

$\mathbf{X}_{\mathbf{3}}=$ Resource mobilization

$\mathbf{X}_{4}=$ Visionary Leadership

$\boldsymbol{e}=$ error term. 


\section{Empirical Results and Discussions \\ Employee Empowerment and Reforms Implementation in National Police Service}

Mean, standard deviation and mode of the responses were estimated for each of the ten attributes of employee empowerment and illustrated in figure 4.1. Results show that the attributes with highest means were "Training improves productivity and performance in the National Police Service" mean being 3.992, "Promotions rely on mentoring relationship with someone higher in rank in the National Police Service" mean being 3.349 and "Junior officers do take responsibility once they are delegated duties" mean being 3.194. The modes for the attributes were 4 . Modal analysis shows that respondents generally agreed that three attributes contribute to employee empowerment in the National Police Service in Nairobi County. Analysis using mean show that respondents were in agreement that training improves productivity and performance but was not sure about the effects of the other two attributes.

Both modal and mean analyses showed that mean was 2.860 and mode were 3 , respectively, for contemporary curriculum. The results show that the respondents were not sure whether or not the contemporary curriculum that has been adopted for the training of police officers is highly sufficient and whether or not it has yielded a high degree of efficacy as regards goals of the National Police Service. This response differs from those of Robert J Redmon (2007) who did a study on Impact of teacher's training upon teachers' self-efficacy and found out that training programs influence the growth of self-efficacy among teachers. Whereas modal analysis shows that the respondents agreed $(\operatorname{mode}=4)$ that transfers in the National Police Service improve service effectiveness, mean analysis showed that the respondents were not sure (mean=2.814) whether transfers improve service effectiveness or not. Analysis using mean $=3.992$ and mode $=4$ shows that the respondents were in agreement that training improves productivity and performance. Findings of this study relates to that of Muhammad Maimuna (2013) who did a research on the influence of employee training and development on employee productivity. The researcher found out that training is valuable in increasing productivity of organization.

Modal and mean analysis (mean 3.349, mode 1.118) for Promotions relying on mentoring relationship with someone higher in rank in the National Police Service. The analysis showed that the respondents agreed. This respond relates with the study done by Angela Copeland (2012), who did a study on how to get promoted, strategies for moving up the corporate ladder. She found out that a higher percentage of people who are promoted are those who are related with people in higher authority in the company.

Both modal and mean analyses show that respondents disagreed that senior officers often delegate duties to their juniors (mean 2.287, mode 2 ) The results yielded from the question are not in agreement with what is happening on the ground. The respondents concluded that senior officers do not delegate duties, practically duties are delegated downwards. The deployment of police officers by police leaders is not always transparent as per response given by the respondents instead favourism is highly practiced. The analysis also showed that deployment in National Police Service is done based on competence in a given field (mean 2.178 , mode 2). Whereas modal analysis showed that the respondents strongly disagreed that the current mode of promotion in the National Police Service is founded on the principle performance and it is a boost to the institution, the response on this question differs from the findings of Laurence J Peter (2010), who observed that an employee is promoted based on their success in previous job performance until they reach a level of incompetence. 
Deployment of officers by leaders is always transparent and that transfer in National Police Service does breed corruption, mean analysis showed that respondents disagreed.

\section{Teamwork and Reforms Implementation in the National Police Service}

The modal analysis (mode of 3) shows that the respondents were not sure whether or not the SSO support teamwork in National Police Service, mean analysis (mean of 2.364) show that they disagreed that SSO supports the issue of teamwork in the National Police Service. From the study findings, most of the respondents disagreed that the SSO support the issue of teamwork in the National Police Service but in reality SSO strongly supports teamwork in the National Police Service

Whereas mean analysis shows that respondents generally disagreed that junior officers are given room to make decisions and follow their hearts (mean of 2.202) and that they also disagreed that there is an open communication between police leaders and their juniors (mean of 1.930), modal analysis shows that the respondents strongly disagreed concerning the two attributes. Both mean and modal analyses show that the respondents disagreed that service terms and conditions encourage creativity and innovations.

The modal analysis (mode of 4) shows that respondents generally agreed that every officer in National Police Service has deep commitment to decision or action in the group, mean analysis (mean of 2.953) shows that the respondents were not sure whether or not every officer in the deep commitment to any decision or action in the group. The researcher is not in agreement with the findings because in National Police Service decision are made by senior officers and not groups.

Variability's of responses were lowest in the following attributes: the SSO support the issue of teamwork in the National Police Service ( 0.844 of standard deviation), the findings contradicts results found in a study done by Emmanuel Osei (2015) on Team Work and Organizational Policies. He found out that team work is an efficient way of achieving organizational goals in an organization; he recommended that organizational policies should tackle on issue of team work. There is interdependence of employees in the National Police Service ( 0.864 of standard deviation) and there is an open communication between police leaders and their juniors (standard deviation of 0.899). Highest variability was witnessed with responses for the following attributes: every police officer in the National Police Service has a deep commitment to any decision or action made in a group (standard deviation of 1.369), junior officers are given room to make decisions and follow their hearts (1.144 of standard deviation). The respondents disagreed with this statement, their response differed with the findings of Casey Anderson (2019) who did a study on Advantages of Employee involvement in decision making and concluded that participation in decision making process gives each employee opportunity to give out their opinions and share their knowledge with others. The respondents also were in agreement that all officers in the National Police Service work towards achieving a common goal (standard deviation of 1.217), this response relates to the findings of the study done by Georgina Stewart (2014) who found out that a successful and productive team in an organization works towards achieving the same goal.

\section{Resource Mobilization and Reforms Implementation in the National Police Service}

Lowest variabilities in responses were seen in the following attributes: the equipment and tools in the National Police Service are sufficient for their operations (standard deviation of 0.870 ) and National Police Service has the right resources needed to in policing to ensure 
efficiency and effectiveness (standard deviation of 0.881). Highest variabilities were in responses on the following attributes: there are enough police personnel in National Police Service(standard deviation of 1.028) and there is enough financial resources to fund the reform implementation (standard deviation of 1.031).

The response from the respondent disagreed about the personnel in National Police Service being enough basing on the report from National Police Service the required number of police officers in Kenya was achieved in 2018 according to the standard of the united nation.

\section{Visionary Leadership the Reforms Implementation in National Police Service}

Modal analysis shows that respondents agreed (mode of 4 ) that some of the characteristics that define leaders in the police service include courage, willingness to take relevant risks and daring. However, mean analysis showed that the respondents were not sure (mean of 3.419). Both modal and mean analyses showed that the respondents generally disagreed that the other attributes in Table 16 affect implementation of reforms in National Police Service divisions in Nairobi County. Respondents disagreed that National Police Service leaders believe in collaboration since they inspire them to realize and release, to the best of their capacity, the uniqueness of their gifts and strengths as a methodology for guaranteeing innovation in the sector, This response is not related with the findings of Herminia Ibara (2011) who did a study on Collaborative Leadership and found out that leaders who value collaboration have a vital source of competitive advantage in today's highly networked business environment.

\section{Reform Implementation in Selected Police Divisions Nairobi County}

Modal analysis shows that the respondents agreed that community policing has created a better rapport between the police departments, this finding is related to a study done by Travis Richardson (2019) on developing an effective understanding of community policing. The researcher found out that the community policing has positively able to improve the existent of relationship between members of the public and the police department. Citizens of the land and also the advent of IPOA led to the reduction of the misconduct of police officers to members of public. The respondents were not sure on whether the foundation upon which the community policing is built has made it possible for the police departments in the country to work hand in hand with members of public with the goal of limiting the rate of crimes in the society. Their response is not related with the findings of Crowl, J, N (2017), who did a study on. The effects of community policing on reduction of crime and fear, legitimacy, job satisfaction and policy. The findings indicate that policies created by the community it focuses on the community's involvement in enforcing law in order to prevent crime. Respondents were not sure, disagreed and strongly disagreed on other factors as indicated in the table. Mean analysis show that the respondents either disagreed or not sure of the factors.

Basing from response from respondent most of them agreed that police leaders are courageous and risk takers but in real sense the junior officers are the one who risk their lives by courageously going to the fields.

\section{Conclusion and Recommendations}

The study concluded that National Police Service should improve on their strategic leadership practices in order to foster implementation of reforms. The areas that require improvement include boosting employee empowerment, teamwork, resource mobilization and leadership. 
The study concluded that employee empowerment improves efficiency and effectiveness of services by junior officers in the National Police Service and it also boosts performance in the institution. Delegation of relevant duties to junior officers promotes responsibility and motivation. The study revealed that participation of all police officers on team work foster meaningful results, so officers in the National Police Service should improve consultation among themselves while on duty.

The study concludes that resource mobilization support achievement of substantive implementation of reforms in the National Police Service. Enough material, human and financial resources will ensure that reform implementation is successful. Lastly, the study concludes that police leadership play a very big role in ensuring that reforms are implemented in the National Police Service, this is only done when they encourage their juniors to push through their difficulties and setbacks.

From the research conclusions, the following measures are recommended for substantive implementation of the reforms in the National Police Service:

The contemporary curriculum should be fine-tuned to respond to the training needs of police officers for highly sufficient and high degree of efficacy to achieve the goals of the National Police Service. The current mode of promotion in the National Police Service should be founded on the principle performance to boost to the institution. Senior officers should delegate relevant duties to their juniors to promote responsibility and motivation. Junior officers should be trained so as to improve productivity and performance in the, National Police Service this should be done based on training needs analysis.

There should be interdependence of employees in the National Police Service to foster meaningful results. Every police officer in the institution should have a deep commitment to any decision or action made in a group for collective responsibility. National police Service should be given right and enough financial resources needed, hence leaders should make good use of them to ensure efficiency and effectiveness of policing and reforms. Leaders in the police service should include courage and willingness to take relevant risks and daring National Police Service leaders should also focus on collaboration to inspire them to realize and release to the best of their capacity, the uniqueness of their gifts and strengths as a methodology for guaranteeing innovation in the sector.

\section{References}

Denick, A. (2011). Validity and Reliability of research characteristics. Chicago: Work Press.

Chtalu. (2014). Challenges related to implementation of police Reforms. Nairobi: Kenyatta University.

Kimathi, P. (2011). Employee empowerment and organizational commitment in state corporations in Kenya. Nairobi: Kenyatta university.

Kitonga, B. (2013). determinants of teacher participation in team work for improved performance in public secondary shools. nairobi: kenyatta university.

Lewin, K. (1947). Change theory. london: kins publishers.

Masaya. (2012). impact of supervisors' empowerment on productivity in a tea manufacturing factory. Meru: meru university.

Mugenda \& Mugenda . (2003). Quantitative and qualitative Approaches. Nairobi: African Centre for Technology Studies.

Mugenda \& Mugenda. (2008). Research methods: Qualitative and quantitative. Nairobi: African Center for Technology studies. 
Mugenda and Mugenda. (2003). Research methods: Qualitative and quantitative. Nairobi: African Center for Technology studies.

Mutua, C. (2014). Effectiveness of Kenya Police reforms on Service delivery. Nairobi: Kenyatta University.

Annet, W. (2015). mobilization and allocation of teaching and learning resources in public secondary schools. Makueni: Kenyatta university.

Wepukhulu, K. (2012). impact of teamwork on performance in the energy sector. Nairobi: Kenyatta university.

Rouse M. (2018). Implanting Strategic Management. Bayler Uuniversity: Texas. 